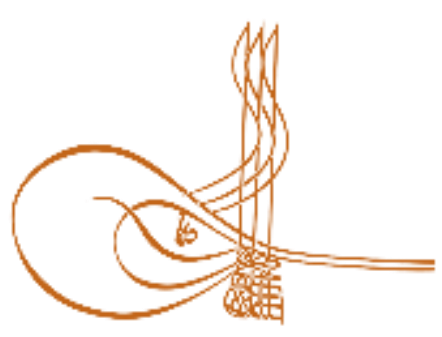

www.turkishstudies.net/social
TurkishStudies-SocialSciences

eISSN: $2667-5617$

ResearchArticle / Araştırma Makalesi

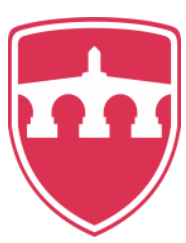

INTERNATIONAL

BALKAN

UNIVERSITY

Sponsoredby IBU

\title{
Gençlerin Suriyelilere Yönelik Yabancı Düş̧manlığına (Zenofobi) Etki Eden Sosyodemografik Faktörler
}

\author{
SociodemographicVariables Influencing Xenophobic Attitudes of theYouth Towards Syrians
}

\author{
Meral Öztürk*
}

\begin{abstract}
The phenomenon of migration, as old as the history of mankind, has transformed into transnational and mass migration in the 21th century. As a result, negative attitudes towards migrants and asylum seekers have significantly increased in the world in the last century. One of these negative attitudes is "xenophobia", a term defined as fear of and hostility towards foreigners. Xenophobia has rapidly increased in Turkey, in particular after the syrian mass migration movement starting from 2011 Syrian internal war. Although xenophobic attitude can be observed in allage groups, it might be more common among the youth who are more likely to encounter Syrians in different social areas due to their active social life. With this assumption, this research aims to examine the impact of sociodemographic variables (gender, occupation, educationa lstatus, marital status, income level, parental education level, political opinion) on the youth's xenophobic attitudes towards Syrians. In the selection of the sample conveniance sampling technique was used. 384 young people aged between 15-32 years participated in the study. A personal information form and a "XenophobiaScale" developed by Van Der Veer, Ommundsen, Yakushko \& Higler (2011) and adapted into Turkish by Özmete, Yıldırım and Duru (2018) were utilized in the study. The predictive power of independent variables was calculated by binary logistic regression analysis. According to the findings, 189 of the participants (50.8\%) were female, and 195 were male (49.2\%), and the average mean of their age was 23 (sd. $\pm 3,31$ ). The participants generally have negative attitudes towards foreigners. Marital status and the level of education predicted the xenophobia level positively. Singles have more negative attitudes towards Syrians than married ones. Similarly, high school graduates are more xenophobic than primary school graduates. On the other hand, income level predicts xenophobia negatively. Lower income groups are more xenophobic towards Syrians than higher income groups.
\end{abstract}

StructuredAbstract: In the $21^{\text {st }}$ century, Xenophobia has become a public concern in all around the world, including Turkey (Güngör, 2017). Xenophobic attitudes of Turkish people have rapidly increased in Turkey, especially after the Syrian mass migration movement after the Syrian Internal War in 2011. The number of Syrians in Turkey has been registered as 3.680.603 people on October 31, 2019.1.994.960 of this population are men and 1.685.643 are women. (https://multeciler.org.tr/turkiyedeki-suriyeli-sayisi-ekim-2019/). The

*Dr. Öğr. Üyesi, Sivas Cumhuriyet Üniversitesi, Edebiyat Fakültesi, Sosyal Hizmet Bölümü Asst. Prof. Dr.,,Sivas Cumhuriyet University, Faculty of Letters, Department of Social Work, ORCID0000-0001-7570-5361

mrozturk@cumhuriyet.edu.tr

Cite as/ Atıf: Öztürk, M. (2020). Gençlerin Suriyelilere yönelik yabancı düşmanlığına (zenofobi) etki eden sosyodemografik faktörler, TurkishStudies -Social, 15(1), 559-576. https://dx.doi.org/10.29228/TurkishStudies.40505

Received/Geliş:10 January/Ocak 2020

Accepted/Kabul:25 February/Şubat 2020

Copyright $($ INTAC LTD, Turkey
Checkedbyplagiarism software

Published/Yayın: 29 February/Şubat 2020

CC BY-NC 4.0 
number of Syrians constitutes approximately $3.72 \%$ of the country's total population (Çiftçi, 2018). Most of theimmigrants are under the age of 35 (Akcan, 2018).

The term "xenophobia" is a combination of two Greek words "xenos" and "phobos". "Xenos" denotes stranger and "phobos" evokes fear, respectively. Thus, xenophobia can be defined as a fear of and hostility towards strangers (Makgopa,2013; Padır, 2009).

The xenophobic attitude may increase over time. Indeed foreigners are often accepted with tolerance, but they can be seen as a threat by local people in time. Xenophobia is transmitted from generation to generation through the socialization process (Litvinova and Tarasov, 2012). Xenophobic attitude stigmatizes strangers as uneducated, lazy and guilty (Yakushko, 2009), creates psychological pressure on strangers on an individual level (Jasinskaja-Lahti, Liebkind and Perhoniemi, 2006), leads to suicides (Hovey, 2000), reduces the psychological harmony between local people and foreigners, results in cultural conflict and confusion, increases crime rates, frightens potential investors, hinders foreign exchange inflows to the country, and shakes the country's external image in a negative way (Kurman, Eshel and Sbeit, 2005; Lakimova, 2018; Yakushko, 2005; Lakimova, 2018; Yakushko, 2005; Lakimova, 2018; Yakushko, 2005; (2009).

A number of factors such as economic competition between local people and foreigners on scarce resources such as work, education and land (Blumer, 1958; Sherif, Harvey, White, Hood, \&Sherif, 1961), the belief in the erosion of cultural values of the host country ( Odiaka, 2017), group nepotism (Tajfel \& Turner 1979),the perception that foreigners get more than they deserve (Harris 2002), the senses of loss of status and control by the dominant group (King, 2007), the idea that foreigners spread disease (Sanchez-Mazas and Licata, 2015), the belief that their nation is superior (Radkiewicz, 2003), holding foreigners responsible for economic and political problems (Aden, 2017), the view that the ethnic balance has deteriorated (Loescher and Miller, 2004), the prevalence of discriminatory discourses on immigrants in the media and especially on social media, and the belief that they pose a threat (Kardeş, Banko and Akman, 2017) may trigger xenophobic attitudes.

Xenophobic attitude may be experienced in different levels depending on sociodemographic variables such as gender, occupation, educational status, marital status, income level, parental education level, and political opinion). Substantial researches have revealed that men (Padir, 2019; Strabac and Listhaug, 2008; Schweitzer, Perkoulidis, Krome and Ludlow, 2005; Quillian, 1995), the unemployed (Schlueter and Wagner, 2008), the poor (Wimmer, 1997), the less educated (Haerpfer and Wallace, 1998), nationalists (Chandler and Tsai, 2001; Ekehammar, Akrami, Gylje and Zakrisson, 2004) and the single (Raijman et al., 2003) are more xenophobic than others. Although xenophobic attitude can be observed in all age groups, it might be more common among the youth who are more likely to encounter Syrians in different social areas due to their active social life. From this assumption, this study aims to examine the impact of sociodemographic variables (gender, occupation, educational status, marital status, income level, parental education level, political opinion) on the youth's xenophobic attitudes towards Syrians.

In the selection of the sample conveniance sampling technique was used. 384 young people aged between 15-32 years participated in the study. A personal information form and a "Xenophobia Scale" developed by Van Der Veer, Ommundsen, Yakushko\&Higler (2011) and adapted into Turkish by Özmete, Yıldırım and Duru (2018) were utilized in the study. The predictive power of independent variables was calculated by binary logistic regression analysis.

According to the findings, 189 of the participants (50.8\%) were female, and 195 were male (49.2\%), and the average mean of their age was 23 (sd. $\pm 3,31$ ). The participants generally have negative attitudes towards foreigners. Marital status and the level of education predicted the xenophobia level positively. Singles have more negative attitudes towards Syrians than married ones. Similarly, high school graduates are more xenophobic than primary school graduates. On the other hand, theincome level predicts xenophobia negatively. Lower income groups are more xenophobic towards Syrians than higher income groups.

Within the framework of the findings, it can be suggested that the Turkish government should reconsider the migration policy of the state, strengthen the social interaction between Syrians and local people, and eliminate the concerns of the latter.

Keywords: Sociology, Young people, Refugee, Asylumseeker, Syrians, Xenophobia, sociodemographic variables 
Öz: İnsanlık tarihi kadar eski olan göç olgusu 21.yüzyılla birlikte şekil değiştirmiş, ulus aşırı ve kitlesel nitelik kazanmıştır. Bunun sonucu olarak tüm dünyada son yüzyılda göçmen ve sığınmacılara yönelik olumsuz tutumlar gözle görülür biçimde artmıştır. Yabancılara yönelik olumsuz tutumlardan birisi de"yabancı korkusu ve düşmanlı̆̆ı" olarak tanımlanan "zenofobi"dir. Zenofobi 2011 yılında Suriye'de başlayan iç savaş sonucu artan Suriyeli göçmen sayısı ile birlikte Türkiye'de de yükselen bir sorun olarak dikkat çekmektedir. Zenofobik tutum tüm yaş gruplarında görülebilmekle birlikte, aktif sosyal yaşamları gereği Suriyelilerle farklı alanlarda karşılaşma ihtimali fazla olan gençler arasında daha yaygın olabilir. $\mathrm{Bu}$ varsayımından hareketle bu araştırma gençlerin zenofobik tutumunu etkileyen sosyodemografik değişkenleri (cinsiyet, meslek, eğitim durumu, medeni durum, gelir düzeyi, anne baba eğitim düzeyi, siyasi görüş) ortaya koymaktadır. Araştırmanın örneklemini tesadüfî örnekleme tekniğiyle belirlenen ve 15-32 yaş aralığında yer alan 384 genç oluşturmaktadır. Araştırmada kişisel bilgi formu ile Van Der Veer, Ommundsen, Yakushko ve Higler (2011) tarafindan geliştirilen Özmete, Yıldırım ve Duru (2018) tarafindan Türkçeye adapte edilen "Yabancı Düşmanlığı (Zenofobi) Ölçeği” kullanılmıştır. Araştırmada bağımsız değiş̧kenlerin bağımlı değişkenleri yordama gücü binary lojistik regresyon analizi ile hesaplanmıştır. Elde edilen bulgulara göre araştırmaya katılanların 189 'u kadın $(\% 50,8), 195$ 'i erkek $(\% 49,2)$ olup, katılımcıların yaş ortalaması 23(ss. $\pm 3,31$ )'tür. Katılımcılar genel olarak yabancılara karşı olumsuz tutuma sahiptir. Medeni durum ve eğitim düzeyi zenofobiyi pozitif yönde anlamlı şekilde yordamaktadır. Bekârlar evlilere kıyasla daha zenofobiktir. Benzer şekilde lise mezunlarının zenofobi düzeyi ilköğetim mezunlarına kıyasla daha yüksektir. Öte yandan gelir düzeyi zenofobiyi negatif yönde yordamaktadır. Alt gelir grubuna mensup olanlar üst gelir grubunda bulunanlara göre Suriyelilere karşı daha zenofobiktir.

Anahtar Kelimeler: Sosyoloji, Genç, Sığınmacı, Mülteci, Suriyeliler, Zenofobi, Sosyodemografik değişkenler

\section{Giriş}

Yabancılara karşı olumsuz tutum ve davranışlar son dönemlerde tüm dünyada kamusal bir sorun haline dönüşmüştür (Güngör, 2017). Bu durum ayrımc1 ideolojilerin siyasetten medyaya, sivil toplum örgütlerinden üniversitelere kadar pek çok farklı alanda tartışılmasına neden olmuştur. $\mathrm{Bu}$ kapsamda "yabancı korkusu veya düşmanlığı" olarak adlandırılan zenofobi olgusu da son dönemlerin popüler konularından birisi haline gelmiştir. Zenofobinin nedenleri ve sonuçları üzerine yapılan bilimsel çalışmalar yabancı korkusu veya düşmanlığının genel olarak yükselmesine karşın bölgeden bölgeye, zamandan zamana değişebildiğini, bireylerin sosyodemografik özelliklerine göre farkl1 düzeylerde yaşanabildiğini göstermektedir(Getmansky, Sınmazdemir ve Zeitzoff, 2018; Padır, 2019). Örneğin Al-Kubaisi ve Soliman (2017) Katar'da yaptıkları çalışmada kadınların zenofobik tutumlarının erkeklerden yüksek olduğunu ayrıca zenofobinin yaş, ailenin eğitim düzeyi ve babanın mesleği ile negatif korelasyon gösterdiğini saptamışlardır. Benzer şekilde Ponce (2017) Avrupa ülkelerinde kadınların Müslüman göçmenlere yönelik tutumlarının erkeklere kıyasla daha olumsuz olduğunu ortaya koymuştur. Bunun aksine erkeklerin yabancilara karşı daha zenofobik olduğunu ortaya koyan çalışmalar da vardır (Padır, 2019; StrabacveListhaug, 2008; Schweitzer, Perkoulidis, Krome ve Ludlow, 2005; Quillian, 1995) Araştırmalar ayrıca işsizlerin (Schlueter ve Wagner, 2008), alt sosyo-ekonomik düzeydeki bireylerin (Wimmer, 1997) eğitim düzeyi düşük olanların (Haerpfer ve Wallace, 1998), milliyetçi ideolojilere sahip olanların (Chandler ve Tsai, 2001; Ekehammar, Akrami, Gylje ve Zakrisson, 2004) ve bekarların (Raijman vd., 2003) yabancılara yönelik olumsuz tutumlarının yüksekliğini de ortaya koymuştur. Ancak sosyodemografik özellikler ile zenofobi arasındaki ilişkiyi inceleyen çalışmaların sınırlı olduğu, yapılan çalışmaların ise çoğunlukla Avrupa ya da Afrika ülkelerinde gerçekleştirildiği (bkz. Best ve Wolf, 2015; Gallego ve Pardos-Prado, 2014; Ponce, 2017), genellikle söz konusu değişkenlerin çalışmalarda kontrol değişkeni (Best ve Wolf, 2015; De Master ve Le Roy, 2000; Gallego ve Pardos-Prado, 2014) olarak kullanıldığ 1 ve 15 yaş üzeri tüm yaş gruplarının çalışmalara dahil edildiği görülmektedir. Türkiye'de ise zenofobinin gittikçe yükselen bir tutum (Padır, 2019) olmasına karşın genel olarak göçmenler ve özelde Suriyelilere yönelik zenofobi ve ayrımcı tutumların sosyodemografik özelliklere göre farklılaşıp farklılaşmadığını inceleyen çok sınırlı 
sayıda çalışma vardır (bkz. Çiftçi, 2018; Padır, 2019). Sosyodemografik değişkenlerin zenofobi üzerindeki etkisine odaklanan çalışmalara ise rastlanmamıştır.

Yukarıdaki eksikliklerden yola çıkarak bu araştırma zenofobik tutumu etkileyen sosyodemografik değişkenlere (cinsiyet, meslek, eğitim durumu, medeni durum, gelir düzeyi ve siyasi görüş) odaklanmakta, söz konusu değişkenlerin zenofobiyi ne düzeyde yordadığını ortaya koymayı amaçlamaktadır. Zenofobi tüm yaş gruplarında ortaya çıkmakla birlikte, gençlerin sosyal yaşamda aktif olmaları nedeniyle yabancılarla daha çok etkileşimde bulunmaları, bu etkileşimin olumsuz deneyimler içerebilmesi ve zenofobik tutuma bağlı olarak işlenen suçların genelde gençler tarafından gerçekleştirilmesi (Sherrod, 2006: 681), zenofobi çalışmalarında gençlerin özel olarak incelenmesi gerekliliğini ortaya koymaktadır. Bu nedenle bu araştırma 15-32 yaş aralığındaki gençlerle gerçekleştirilmiştir. Her ne kadar Birleşmiş Milletler genç nüfus olarak 15-24 yaş aralığını referans alsa da yüksek öğrenimin yaygınlaşması, kentleşme, işe giriş ve evlenme yaşının yükselmesi gibi nedenler gençlik yaşının uzamasına neden olmuş (Şener, Yücel ve Yedikardeş, 2018) buna bağlı olarak UN Habitat (Gençlik Fonu) 15-32 yaş grubunda bulunanları genç olarak tanımlamıştır (https://www.un.org). Bu araştırmanın tutumları etkileyen faktörleri ortaya koyarak gelecekte yaşanması muhtemel gruplar arası çatışma ve şiddetin önüne geçilmesine (Getmansky, Sınmazdemir ve Zeitzoff, 2018) ve yabancı düşmanlığı ile ilişkili kalıpları tanımlamaya yardımcı olabilecek bilgi havuzunun oluşturulmasına katkı sunacağı düşünülmektedir.

\section{Zenofobinin Tanımlanması, Nedenleri ve Sonuçları}

Yunanca "xenos (yabanc1)" ve "phobos (korku)" kelimelerinden türetilen (Makgopa,2013) zenofobi kısaca "yabancı korkusu" anlamına gelmektedir. Ancak kavramın tam olarak ne içerdiği konusu tartışmalıdır (UNHCR, 2015). Bu tartışmanın bir nedeni kavramın özünde yer alan "yabancı" terimine yüklenen farklı anlamlardır. Esasen "buralı olmayan, başka türden olan, tuhaf, farklı, öteki, başkası, dışarıdan olan, aşina olunmayan gibi iç ve dış arasındaki sınırları belirleme çabalarına" işaret eden yabancı kavramı (Waldenfells, 2008 akt. Güngör, 2017), zenofobi tanımlarında kimi zaman hemen bitişiğimizdeki bir kişiyi içerecek şekilde kimi zaman bizden tamamen farklı bir kişi veya grubu vurgulayacak şekilde kullanılmaktadır. Zenofobinin hangi düzeyde (bireysel/kamusal) yaşandığı da tanımını farklılaştırmaktadır. Bireysel düzeyde zenofobi kendinden farklı olanlara karşı yoğun korkuyu içerirken; kamusal düzeyde göçmenler gibi belirli insan grubundan hoşlanmama veya nefret etme şeklinde tezahür etmektedir. Kamusal düzeyde zenofobi çoğu zaman mantıklı açıklamalarla gerekçelendirilmektedir (Lakimova, 2018). Bu tartışmalar altında Campbell ve McCantless (1951) zenofobiyi "yabancılara yönelik önyarg1 ve tutum" olarak tanımlarken Reynolds, Falger ve Vine (1987: 28) "yabancı olduğu düşünülen kişilere yönelik mantıksız, sebepsiz korku ve nefretin psikolojik hali (durum)" olarak kavramlaştırmaktadır. Rydgren (2004) zenofobiyi yabancılara yönelik korku, nefret, önyargı, öfke gibi duyguları içeren duygusal, tutumsal veya davranışsal bir önyargı formu olarak görmektedir. Uluslararası düzeyde resmi kuruluşlar ise "toplum, toplum veya ulusal kimliğe yabancı veya yabancı oldukları algısına dayanarak insanları dışlayan ve sık sık kötüleştiren tavırlar, önyargılar ve davranışlar"ızenofobi olarak tanımlamaktadır (Miller, 2018). Sundstrom (2013) zenofobinin özünde buraya ait olmadığ1 düşünülen yabancıları vatandaşlıktan dışlama ve uzaklaştırma inancı olduğunu ancak bunun öznel bir inanç olduğunu genellikle, kendisini ulusa ait hisseden bireyin, başka bir kişi veya grubun bu milletin bir parçası olamayacağı düşüncesinden kaynaklandığını öne sürmektedir. "Zenofobi, ayrıca yabancılara karşı hoşgörüsüzlüğü de içeren, yabancı düşmanlığı olarak da tanımlanmaktadır" (Padır, 2009).

Zenofobik tutum zamanla ortaya çıkmakta, çoğu zaman başta hoşgörüyle kabul edilen yabancılar zaman içerisinde tehdit unsuru olarak görülebilmekte; bu tehdit şiddet, kızgınlık, düşmanlık veya sözlü ve fiziksel olarak istismar etme gibi şekillerle zenofobiye yol açabilmektedir (Lesetedi ve Modie-Moroka 2007). Zenofobi sosyalleşme süreciyle kuşaktan kuşağa aktarılmaktadır (Litvinova ve Tarasov, 2012). 
Zenofobinin çok boyutlu bir kavram olması zenofobiye neden olan faktörleri de karmaşıklaştırmaktadır (Yakushko, 2009). Yerli halk ile yabancılar arasında iş, eğitim ve toprak gibi kit kaynaklara ulaşmak için yaşanan ekonomik rekabet (Blumer, 1958; Sherif, Harvey, White, Hood, ve Sherif, 1961), kültürel değerlerin farkl1lı̆̆1, yerel halkın yabancilar nedeniyle kendi kültürel değerlerinin aşındığını düşünmesi (Odıaka, 2017), grup kayırmacılığı (Tajfel ve Turner 1979), yabancıların hak ettiklerinden fazlasını aldığ1 algısı (Harris 2002) hakim grubun kendi statüsünü ve kontrolünü kaybettiği duygusu (King, 2007), yabancıların hastalık yaydığı düşüncesi (Sanchez-Mazas ve Licata, 2015), kendi milletinin üstün olduğu inancı (Radkiewicz, 2003), yabancıların ekonomik ve politik problemlerden sorumlu tutulması (Aden, 2017), etnik dengenin bozulduğu görüşü (Loescher ve Miller, 2004), medyada ve özellikle sosyal medyada göçmenlere yönelik ayrımcı söylemlerin yaygınlığı ve yabancıların iç güvenlik için tehdit oluşturdukları inancı (Kardeş, Banko ve Akman, 2017) gibi pek çok faktör zenofobiye neden olabilmektedir.

Zenofobik tutum yabancıları eğitimsiz, tembel ve suçlu olarak damgalamakta(Yakushko, 2009), bu durum hem bireysel hem de toplumsal düzeyde pek çok olumsuzluklara neden olmaktadır. Bireysel düzeyde yabancılar üzerinde psikolojik baskı yaratarak ruhsal iyiliği düşürmekte (Jasinskaja-Lahti, Liebkind ve Perhoniemi,2006) hatta intiharlara neden olabilmektedir (Hovey, 2000). Toplumsal düzeyde yerel halk ve yabancilar arasında psikolojik uyumu azaltarak, kültürel çatışma ve karmaşaya yol açmakta, suç oranlarını artırmakta, potansiyel yatırımcıları korkutarak ülkeye döviz girdisini engellemekte ve ülkenin dışarıdaki imajını kötü yönde sarsmaktadır (Kurman, Eshel ve Sbeit, 2005; Lakimova, 2018; Yakushko, 2009).

\section{Türkiye'de Göçmen ve Sığınmacılar}

Birleşmiş Milletler (BM) Mülteci Örgütü'nün verilerine göre 2017 yılı sonu itibarıyla 68,5 milyon kişi yerinden edilmiştir. Bunlar içinde, 16,2 milyon kişi, 2017 yılı içerisinde, ya ilk kez ya da üst üste birçok kez olmak üzere yerinden edilmiştir. Bu rakam her gün 44.500 kişinin göç ettiğini göstermektedir. 68,5 milyonun, 25,4 milyonunu ise ülkelerinde yaşanan çatışma ve zulüm nedeniyle evlerini terk eden mülteciler oluşturmuştur. Zorla yerinden edilenlerin çoğunluğu Filistin, Suriye, Afganistan, Güney Sudan, Myanmar ve Somali gibi ülkelerdendir (UNCHR, 2015). 2018 yılında bu rakam 70 milyon 800 bine çıkmıştır. Bu veri dünya çapındaki mülteci ve göçmen sayısı açısından bir rekor olarak kabul edilmektedir (UNHCR, 2018).

Türkiye tarih boyunca jeopolitik konumu nedeniyle göçmenler için cazibe merkezlerinden birisi olmuş, Türkiye'nin demokratik yapısı, ekonomik gelişimi ve komşu ülkelerde yaşanan siyasi istikrarsızlıklar ve savaşlar yoğun göç almasına neden olmuştur (Nurdoğan ve Doğan, 2019). Resmi raporlar ülkede mülteci, şartlı mülteci ve ikincil koruma statüsünde 3.9 milyon yabancının yaşadığını gözler önüne sermektedir (https://www.unhcr.org).Bunların çok önemli bir kısmı Suriye'den gelenlerden oluşmaktadır. 2011 yılında başlayan ve 8 yıldır devam eden savaş 13 milyondan fazla kişinin evlerini terk etmelerine, 6 milyon 184 bininin ülke içinde yer değiştirmesine, 6 milyon 654 bin kişinin başka ülkelere sığınmasına neden olmuştur (https://www.trthaber.com). Savaştan kaçan Suriyelilerin en çok tercih ettiği ülke Türkiye'dir. Türkiye'deki kayıtlı Suriyeli sayısı 31 Ekim 2019 tarihi itibarıly t3 milyon 680 bin 603 kişidir. Bunların 1 milyon 994 bin 960' 1 erkek, 1 milyon 685 bin 643'ü ise kadındır. (https://multeciler.org.tr/turkiyedeki-suriyeli-sayisi-ekim-2019/). Suriyeli sı̆ğnmacıların sayıları ülke nüfusunun yaklaşık \%3,72'sine denk gelmektedir (Çiftçi, 2018). Suriyeli göçmenlerin yaklaşık \%78'i 35 yaş ve altındadır (Akcan, 2018).

Suriyelilerin Türkiye'yi tercih etmesinde dini, kültürel, coğrafi yakınlık yanında Türk devletinin uyguladığı “açık kapı politikası"nın etkisi büyüktür. Söz konusu politika gereği Suriyelilere "Geçici Koruma Statüsü" verilmiş ve hiçbiri sınırdan çevrilmemiştir (Orhan ve Gündoğar, 2015; Özdemir, 2017). Türkiye'deki Suriyeli sığınmaci/mülteciler ilk aşamada sadece sınır illerinde ve kamplarda ikamet etmişler, iç savaşın uzaması ve kamp sayısının yetersiz 
kalmasıyla ülkenin neredeyse tamamına dağılmışlardır (TÜRKSAM, 2018). Günümüzde Suriyelilerin yaklaşık \%98,3’ünün şehirlerde yaşadığı görülmektedir (https://multeciler.org.tr).

\section{Araştırmanın Yöntemi}

Araştırmada çalışmanın amacına uygun olacak şekilde nicel araştırma modellerinden ilişkisel tarama modeli kullanılmıştır.

\section{Araştırmanın Evren ve Örneklemi}

$\mathrm{Bu}$ araştırma Sivas il merkezinde yaşayan 15-32 yaş aralığındaki gençlerle yapılmıştır. Sivas'ta söz konusu yaş aralığındaki nüfus sayısına kesin olarak ulaşılamamıştır. Evrenin tam olarak bilinemediği durumlarda örneklem $\mathrm{n}=\left(\mathrm{t}^{2}(\mathrm{p} . \mathrm{q}) / \mathrm{d}^{2}\right.$ formülünden hesaplanmaktadır (Baş, 2010). Söz konusu formül kullanılarak yapılan hesaplamada örneklem büyüklügünün 384 olması gerektiği saptanmıştır. Çalışmada güven aralığı 0,95 , hata payı ise 0,05 olarak belirlenmiştir. Örneklemin belirlenmesinde kolayda örnekleme tekniği kullanılmış, katılımcılara çoğunlukla sosyal hizmet bölümünde okuyan öğrenciler aracılığıyla ulaşılmıştır. Öğrenciler anketi yakınlarına ve çevrelerindeki gençlere uygulamış araştırmaya katılmayı kabul eden 410 kişi çalışma gerçekleştirilmiştir. Ancak 26 anket hatalı doldurulması nedeniyle analizden çıkarılmıştır.

\section{Araştırmanın Veri Toplama Araçları} kullanılmıştır.

Araştırmada kişisel bilgi formu ile "Yabancı Düşmanlığı (Zenofobi) Ölçeği"

Kişisel bilgi formu araştırmacı tarafindan oluşturulmuş olup katılımcıların cinsiyetini, yaşını, medeni durum, eğitim ve gelir düzeyleri ile siyasi görüşlerini içeren sorulardan oluşmaktadır.

Yabancı Düşmanlığı (Zenofobi) Ölçeği (YDÖ) Van Der Veer, Ommundsen, Yakushko ve Higler (2011) tarafından geliştirilmiştir. Ölçek 14 maddeden ve 6'lı likert tipi cevaplardan oluşmaktadır. Ölçekte $1=$ kesinlikle katılmıyorum, $6=$ kesinlikle katılıyorum anlamına gelmektedir. YDÖ; Özmete, Yıldırım ve Duru (2018) tarafından Türkçeye adapte edilmiştir. Ölçeğin geçerlilik çalışmaları sonucunda 3 maddesi çıkarılmış 11 maddeli tek faktörlü bir yapı elde edilmiştir. Ölçekten alınabilecek en düşük puan 11, en yüksek puan 66 olup, puanın yükselmesi yabancı düşmanlığ 1 riskinin arttığ1 anlamına gelmektedir. Ölçeğe uygulanan doğrulayıcı faktör analizinde şu değerler bulunmuştur: $(\chi 2 / \mathrm{sd}=4,09), \mathrm{RMSEA}=0,073, \mathrm{SRMR}=$ $0,073, \mathrm{CFI}=0,96, \mathrm{NFI}=0,96, \mathrm{NNFI}=0,95$. Sonuçlar ölçeğin Türk toplumu için uygunluğunu kanıtlamıştır. YDÖ'önünCronbach Alfa iç tutarlılık katsayısı 0,87'dir.

Bu çalışma kapsamında ölçeğin bu araştırma için geçerliliği ve güvenirliği yeniden hesaplanmıştır. Hair, Black, Babin ve Anderson, (2014: 606) daha önce geliştirilmiş, geçerliliği ve güvenirliği test edilmiş bir ölçeğin her yeni çalışmada veri setine uygun olup olmadığını test etmenin faydalı olacağını söylemekte, ölçeğe yeniden gerçelik ve güvenirlik çalışması yapmayı tavsiye etmektedir.

\section{YDÖ İçin Açıklayıcı Faktör Analizi}

YDÖ’nün yapı geçerliliği için önce Açıklayıcı Faktör Analizi (AFA) yapılmıştır. Yapılan analizde sekizinci madde (Göçmenlerin kriz zamanlarında ülkemi destekleyeceğine inanırım) düşük faktör yükü nedeniyle ölçekten çıkarılarak AFA tekrarlanmıştır. Kalan 10 maddeye tekrar faktör analizi yapılmış ve tek faktörlü bir yapı elde edilmiştir. Tek faktör toplam varyansın $\% 42$ 'sini açıklamaktadır. 
Tablo 1: AFA Sonuçları

\begin{tabular}{cccc}
\hline Maddeler & Faktör yükleri & Özdeğer & Kümülatif varyans \\
\hline s1 &, 764 & 41,940 & 41,940 \\
s2 &, 728 & & \\
s3 &, 742 & & \\
s4 &, 747 & & \\
s5 &, 577 & & \\
s6 &, 666 & & \\
s7 &, 573 & & \\
S8 &, 712 & & \\
S9 &, 599 & & \\
s10 &, 647 & & \\
\hline
\end{tabular}

KMO: 0,895Barlett Test: 1387,529Öz Değer: 1'den fazla Anlamlılık: 0.000

\section{YDÖ için Doğrulayıcı Faktör Analizi}

AFA'nın ardından Doğrulayıcı Faktör Analizi (DFA) yapılmıștır. AMOS 23 Programı kullanılarak yapılan DFA'da ölçeğin tek bileşenli yapıya uyum sağlamadığı görülmüş, aralarında yüksek ilişki bulunan e1-e2 ile e5-e6 gizil değişkenler arasında modifikasyon işlemi yapılmıştır. böylece ölçeğin uyum iyiliği değerlerinin kabul edilebilir standartlara ulaşması sağlanmıştır.

Şekil 1. Yabancı Düşmanlığı (Zenofobi) Ölçeği Path Analizi

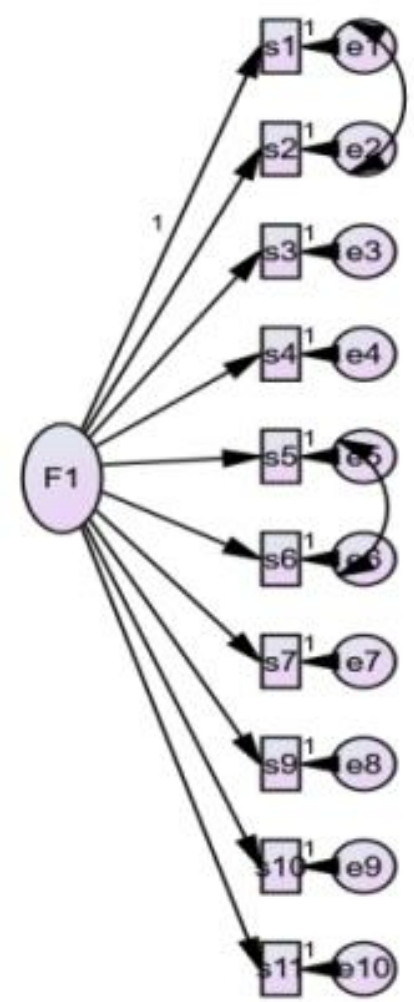

Doğrulayıcı faktör analizinin uyum iyiliği değerleri ölçeğin doğrulandığını göstermektedir. Uyum iyiliği değer aralıkları Gürbüz ve Şahin (2015: 337)'nin belirttiği “kabul edilebilir “ standartlara göre düzenlenmiştir. Bulgular Tablo 2'te verilmiştir. 
Tablo 2:Ölçeğe Ait Uyum İyiliği Değerleri

\begin{tabular}{llllllllll}
\hline & & & CMIN/ & GFI & AGFI & CFI & NFI & TLI & RMSEA \\
Ölçek & $\mathbf{X}^{2}$ & Df & DF $\leq \mathbf{5}$ & $\mathbf{2 . 8 5}$ & $\mathbf{2 . 8 0}$ & $\mathbf{2 . 9 0}$ & $\mathbf{2 . 9 0}$ & $\mathbf{\geq . 9 0}$ & $\leq . \mathbf{0 8}$ \\
\hline YDÖ & 96,140 & 33 & 2,91 & .95 & .92 & .95 & .93 & .94 & .07 \\
\hline
\end{tabular}

\section{YDÖ için Güvenirlik Analizi}

YDÖ Ölçeğinin güvenilirlik katsayısı 0,88 olarak hesaplanmıştır. Bu ölçeğin güvenirliğinin oldukça yüksek olduğunu ve bu araştırma için kullanılabileceğini göstermektedir.

\section{Araştırmada Kullanılan İstatistiksel İşlemler}

Araştırmada elde edilen bilgilerin çözümlenmesi SPSS 23 paket programı ile yapılmış olup öncelikle araştırmada kullanılan ölçeğin bu veri seti için geçerliliği ve güvenirliği yeniden hesaplanmıştır. Ardından verilerin analizinde frekans ve yüzdelik dağılımı ile bağımsız değişkenlerin bağımlı değişkeni yordama gücü için binarylojistik regresyon analizi yapılmıştır.

\section{Bulgular}

\section{Örneklemin Sosyo-Demografik Özellikleri}

Araştırmaya katılanların 195'i (\%49,2), erkek 189'u(\%50,8) kadın; 249'u (\%64,8) öğrenci 112 'si $(\% 29,2)$ çalışandır. Katılımcıların 23'ü (\%6) ise herhangi bir işte çalışmadığını söylemiştir. Katılımciların 273'ü (\%71) üniversite öğrencilerinden oluşurken 111'i (\%29)lise ve altında eğitim düzeyine sahip olduğunu ifade etmiştir. Gençlerin 164'ü (\%42,7) evli, 217'si (\%56,5) bekâr; 131'i2000 TL ve altında (\%34,1), 183'ü(\%47,7) 2001-4000 TL,70'i $(\% 18,2)$ ise 4001 TL ve üzerinde gelire sahip olduğunu söylemiştir. Katılımcıların çoğunluğu $(\% 27,6)$ kendisini milliyetçi olarak tanımlamaktadır. Araştırmaya katılanların yaş ortalaması 23, 83 (ss. $\pm 3,31$ )'dir.

Tablo 3: Kat1lımc1lara Ait Betimsel İstatistikler

\begin{tabular}{clcc}
\hline & Değişkenler & $\mathbf{N}$ & $\mathbf{\%}$ \\
\hline \multirow{2}{*}{ Cinsiyet } & Kadın & 189 & 50,8 \\
& Erkek & 195 & 49,2 \\
\hline \multirow{3}{*}{ Meslek } & Öğrenci & 249 & 64,8 \\
& Çalışmayan & 23 & 6 \\
& Çalışan & 112 & 29,2 \\
\hline \multirow{2}{*}{ Eğitim } & İlköğretim & 82 & 21,4 \\
düzeyi & Lise & 29 & 7,6 \\
& Üniversite & 273 & 71,1 \\
\hline \multirow{2}{*}{ Medeni } & Evli & 164 & 42,7 \\
durum & Bekar & 217 & 56,5 \\
\hline \multirow{2}{*}{ Algılanan } & 2000 TL ve altı & 131 & 34,1 \\
Gelir & 2001 TL-4000 TL & 183 & 47,7 \\
& 4001 TL ve üzeri & 70 & 18,2 \\
\hline \multirow{5}{*}{ Siyasi } & Liberal & 20 & 5,2 \\
görüş & Muhafazakar & 33 & 8,6 \\
& Sağc1 & 29 & 7,6 \\
& Solcu & 24 & 6,3 \\
& Milliyetçi & 106 & 27,6 \\
& Milliyetçi muhafazakar & 60 & 15,6 \\
& Diğer & 91 & 23,7 \\
& Kayıpveri & 21 & 5,5 \\
\hline
\end{tabular}




\section{Katılımcıların Yabancı Düşmanlığı Düzeyleri}

Katılımcıların YDÖ'den aldıkları ortalama puan 4,23 olup bu değer yabancılara karşı olumsuz tutuma sahip olduklarını göstermektedir. YDÖ maddelerine verilen cevaplar tek tek incelendiğinde en yüksek ortalamanın "Sinırlar, göçmenlerin bu ülkeye girmesini önlemek için daha güvenli hâle getirilmelidir." (Ort: 4,75) maddesinden alındığı bunu "Göçmenler burada yaşayan insanların işlerini almaktadırlar." (Ort: 4,55) ile "Bu ülkedeki göç/göçmenlik kontrolden çıkmaktadır. " (Ort: 4,53) maddelerinin takip ettiği görülmektedir. Katılımcılar en düşük ortalamay1 ise "Göçmenlerle etkileşim kurmak beni tedirgin eder." (Ort:3,32) maddesinden almışlardır.

Tablo 3: YDÖ’nün Maddelerine İlișkinBetimsel İstatistik

\begin{tabular}{lcccccc}
\hline Maddeler & $\mathrm{N}$ & Min. & Max. & $\chi$ & ss. \\
\hline $\begin{array}{l}\text { 1.Bu ülkedeki göç̧göçmenlik kontrolden } \\
\text { çkmaktadır. }\end{array}$ & 384 & 1 & 6 & 4,53 & 1,512 \\
\hline $\begin{array}{l}\text { 2.Sınırlar, göçmenlerin bu ülkeye girmesini } \\
\text { önlemek için daha güvenli hâle getirilmelidir. }\end{array}$ & 384 & 1 & 6 & 4,75 & 1,461 \\
\hline 3.Göçmenler suçlarda artışa neden olmaktadır & 384 & 1 & 6 & 4,52 & 1,459 \\
\hline $\begin{array}{l}\text { 4.Göçmenler burada yaşayan insanların işlerini } \\
\text { almaktadırlar }\end{array}$ & 384 & 1 & 6 & 4,55 & 1,527 \\
\hline $\begin{array}{l}\text { 5.Göçmenlerle etkileşim kurmak beni tedirgin } \\
\text { eder. }\end{array}$ & 384 & 1 & 6 & 3,32 & 1,646 \\
\hline $\begin{array}{l}\text { 6.Göçmenlerin olağandışı hastalıklar } \\
\text { yayabileceğinden endişe ederim. }\end{array}$ & 384 & 1 & 6 & 4,00 & 1,608 \\
\hline $\begin{array}{l}\text { 7.Savaş ya da siyasi gerginlik durumunda } \\
\text { göçmenlerin kök ülkelerine sadık kalacaklarından } \\
\text { korkarım. }\end{array}$ & 384 & 1 & 6 & 4,44 & 1,496 \\
\hline $\begin{array}{l}\text { 8.Gittikçe artan göçlerle, hayatımın kötüleşece- } \\
\text { ginden korkarım. }\end{array}$ & 384 & 1 & 6 & 4,13 & 1,627 \\
\hline $\begin{array}{l}\text { 9.Göçmenlerin bu ülkeye öncelikle ilgi } \\
\text { göstereceklerinden şüphe ederim. }\end{array}$ & 384 & 1 & 6 & 4,13 & 1,567 \\
\hline $\begin{array}{l}\text { 10.Göç arttıkça kendi kültürümüzün } \\
\text { kaybolacağından korkarım. }\end{array}$ & 384 & 1 & 6 & 4,39 & 1,614 \\
\hline YDÖ Toplam & 384 & 1 & 6 & 4,23 & 0,97 \\
\hline
\end{tabular}

\section{Sosyo-demografik Değişkenler ve Yabancı Düşmanlığı}

Bağımsız değişkenlerin bağımlı değişkenin ne kadarını açıkladığı binary lojistik regresyon analizi ile test edilmiştir. Binary lojistik regresyon analizi, bağımlı değişkenin iki durumlu olduğunda bağımsız değişkenler ile bağıml değişkenler arasındaki ilişkinin incelenmesinde kullanılan istatistiksel analizlerden birisidir. $\mathrm{Bu}$ analiz bağımsız değişkenlerin her birinin risk faktörü olarak anlamlılı̆̆ının değerlendirilmesi yanında tahmini riski (Oddsratio) hesaplama olanağını da sağlamaktadır. Binary lojistik regresyon analizine alınacak bağımsız değişkenler sürekli, sıralı veya kesikli olabilir (Bkz.: Kılıç, 2015).

$\mathrm{Bu}$ çalışmada cinsiyet, yaş, meslek, eğitim düzeyi, medeni durum, gelir düzeyi ve siyasi görüş gibi sürekli ya da kategorik cevap seçeneklerinden oluşan bağımsız değişkenler analize dahil edilmiştir. Bağımlı değişken olan zenofobi "hiyerarşik kümeleme analizi" kullanılarak düşük ve yüksek zenofobi düzeyi diye iki gruba ayrılmıştır. Hiyerarşik kümeleme analizi benzer özelliğe sahip objeleri veya olayları gruplandırarak incelemeye olanaklı kılmaktadır (Koç, 2001). Hiyerarşik kümeleme tekniği kümeleri peş peşe birleştirme sürecidir ve bir grup diğeriyle bir kez birleştikten sonra daha sonraki adımlarda kesinlikle ayrilamaz (Frrat, 1997).

Genel olarak lojistik regresyon analizinde doğru modelleme önemlidir. Modele alınacak değişkenlerin doğru tahmin edilmesi içindoğru modelleme yapmak gerekmektedir (Kılıç, 2015). Bu 
çalışmada modelin doğru kurulduğu sınıflandırma tablosundan görülmektedir. Model kurulmadan önce SPSS'in her bir katılımc1 için doğru kategoriyi tahmin etme yüzdesi \%68 iken modelimizle birlikte bu oran \%75,3'e yükselmiştir. Modelimizde düşük zenofobi düzeyine sahip olanların $\% 87,6$ 's1 yüksek zenofobi düzeyine sahip olanların \%49,2'si doğru tahmin edilmiştir. Bu durum modelimizin doğru kurulduğunu göstermesi bakımından önemlidir.

Tablo 4: Modelin Sinıflandirma Tablosu

\begin{tabular}{|c|c|c|c|c|c|}
\hline & \multicolumn{2}{|l|}{ Gözlenen } & \multicolumn{3}{|c|}{ Tahmin Edilen } \\
\hline & & & \multicolumn{2}{|c|}{ WardMethod } & \multirow{2}{*}{$\%$} \\
\hline & & & Düşük & Yüksek & \\
\hline Step 1 & Zenofobi & Düşük & 227 & 32 & 87,6 \\
\hline & & Yüksek & 62 & 60 & 49,2 \\
\hline & & & & & 75,3 \\
\hline
\end{tabular}

Araştırmada kurulan modellemenin uyum iyiliğinin sağlanıp sağlanmadığ HosmerandLemeshow testi (H-L testi) ile kontrol edilmişolup H-L testinin anlamlı bulunmadığı ve dolayısıyla modelin verileri itibariyle uygun olduğu tespit edilmiştir $\left(x^{2}=9,251 ; p>0.05\right)$.

Tablo 5: Modelin Uyum İyiliği

\begin{tabular}{|c|c|c|c|}
\hline Step & Chi-Square & sd. & p \\
\hline 1 & 9,251 & 8 & 0,322 \\
\hline
\end{tabular}

Çalışmada model katsayılarının anlamlı olduğu yani bağımsız değişkenlerin bağımlı değişkenin yordanmasına katkı sağladığı da anlaşılmıştır $(p<0,05)$.

Tablo 6: Model Katsayılarının Anlamlılığ1

\begin{tabular}{|l|l|l|l|l|}
\hline & & Chi-Square & sd. & p \\
\hline Step 1 & Step & 111,597 & 16 & 0,00 \\
\hline & Block & 111,597 & 16 & 0,00 \\
\hline & Model & 111,597 & 16 & 0,00 \\
\hline
\end{tabular}

Modeldeki bağımlı değişkenlerdeki değişimlerin ne kadarının bağımsız değişkenlerce açıklandığına bakılmış Cox ve Snell R Square değerine göre bu oranın \%26, Nagelkerke R Square değerine göre \%36 olduğu anlaşılmıştır. Lojistik regresyon analizinde genellikle Nagelkerke R Square değeri rapor edildiğinden bu çalışma için bağımsız değişkenlerin bağımlı değişkenleri yordama gücünün \%36 olduğunu söylemek mümkündür. Bu oldukça iyi bir açılama yüzdesine denk gelmektedir.

Tablo 7: Değișkenler Arasındaki İlișkinin Derecesi

\begin{tabular}{|c|c|c|c|}
\hline Step & -2 loglikelihood & Cox\&Snell R Square & Nagelkerke R Square \\
\hline 1 & 366,199 & 0,255 & 0,355 \\
\hline
\end{tabular}

Araştırmada medeni durum, eğitim ve gelir düzeyinin genel olarak zenofobi düzeyini anlamlı şekilde yordadığı tespit edilmiştir. Lojistik regresyon analizinde medeni durum için $0=$ Evli, 1=Bekar olarak kodlanmış, referans kategorisi olarak evli seçeneği belirlenmiştir. Bağımlı değişkenin referans kategorisi ise düşük zenofobi düzeyidir. Tabloya bakıldığında medeni durum ile zenofobi arsında pozitif yönlü anlamlı ilişkinin olduğu görülmektedir. Buradan bekârların zenofobi düzeyinin daha yüksek olduğu söylenebilir. Bekâr olanların yabancılara yönelik olumsuz tutumu evlilere kıyasla yaklaşık 4,5 kat daha yüksektir. 
Binary lojistik regresyon analizi sonucuna göre eğitim düzeyi zenofobiyi pozitif yönde etkilemektedir. Bu etki ilköğretim ile lise mezunlarının yer aldığı gruplardan kaynaklanmaktadır. $\mathrm{Bu}$ grupta ilköğretim düzeyi referans kategorisi olarak belirlenmiştir. Buradan lise mezunlarının daha zenofobik olduğu sonucuna ulaş1labilir. Lise mezunlarının zenofobi düzeyi ilköğretim ve altına kıyasla 6,5 kat daha yüksektir.

Gelir düzeyi ve zenofobi arasındaki ise negatif yönlüdür. Gelir değişkeni alt=1, orta=2, yüksek=3 olarak kodlanmış, referans kategorisi olarak alt gelir grubu seçilmiştir. Gelir düzeyinde zenofobi bakımından farklılaşma düşük ve yüksek gelir grubu arasındadır. Buradan yola çıkarak gelir düzeyi yükseldikçe zenofobi düzeyinin düştüğü söylenebilir. Alt gelir düzeyinin zenofobidüzeyi üst gruba kıyasla 0,4 kat daha yüksektir.

Tablo 8: Modelin Parametrelerinin Anlamlılıklarının İfade Edilmesi

\begin{tabular}{|c|c|c|c|c|c|c|c|c|}
\hline & \multirow[b]{2}{*}{ B } & \multirow[b]{2}{*}{ S.E. } & \multirow[b]{2}{*}{ Wald } & \multirow[b]{2}{*}{ Sd. } & \multirow[b]{2}{*}{$\mathbf{P}$} & \multirow[b]{2}{*}{$\operatorname{Exp}(B)$} & \multicolumn{2}{|c|}{$95 \%$ C.I. for $\operatorname{EXP}(B)$} \\
\hline & & & & & & & Lower & Upper \\
\hline Cinsiyet (1) & 0,431 & 0,273 & 2,491 & 1 & 0,115 & 1,540 & 0,901 & 2,631 \\
\hline Medeni durum (1) & 1,496 & 0,279 & 28,837 & 1 & $\mathbf{0 , 0 0 0}$ & 4,462 & 2,585 & 7,703 \\
\hline Yaş & $-0,095$ & 0,61 & 2,444 & 1 & 0,118 & 0,909 & 0,807 & 1,024 \\
\hline Meslek & & & 3,402 & 2 & 0,183 & & & \\
\hline Meslek (1) & 1,358 & 0,775 & 3,072 & 1 & 0,080 & 3,890 & 0,852 & 17,767 \\
\hline Meslek (2) & 1,312 & 0,735 & 3,191 & 1 & 0,074 & 3,714 & 0,880 & 15,670 \\
\hline Ĕgitim & & & 25,894 & 2 & $\mathbf{0 , 0 0 0}$ & & & \\
\hline Ĕ̆itim (1) & 1,876 & 0,385 & 23,701 & 1 & $\mathbf{0 , 0 0 0}$ & 6,530 & 3,068 & 13,899 \\
\hline Eğitim (2) & $-0,095$ & 0,588 & 0,026 & 1 & 0,872 & 0,910 & 0,287 & 2,878 \\
\hline Gelir & & & 5,595 & 2 & 0,061 & & & \\
\hline Gelir (1) & $-0,251$ & 0,351 & 0,508 & 1 & 0,476 & 0,778 & 0,391 & 1,550 \\
\hline Gelir (2) & $-0,918$ & 0,416 & 4,860 & 1 & $\mathbf{0 , 0 2 7}$ & 0,399 & 0,177 & 0,903 \\
\hline Siyasi Görüşs & & & 8,749 & 7 & 0,271 & & & \\
\hline Siyasi Görüş(1) & 0,086 & 0,636 & 0,018 & 1 & 0,893 & 1,090 & 0,313 & 3,792 \\
\hline Siyasi Görüşs (2) & $-0,961$ & 0,585 & 2,698 & 1 & 0,100 & 0,382 & 0,121 & 1,204 \\
\hline Siyasi Görüş (3) & $-0,709$ & 0,579 & 1,501 & 1 & 0,221 & 0,492 & 0,158 & 1,530 \\
\hline Siyasi Görüş (4) & $-0,268$ & 0,607 & 0,194 & 1 & 0,659 & 0,765 & 0,233 & 2,516 \\
\hline Siyasi Görüş (5) & 0,836 & 0,649 & 1,662 & 1 & 0,197 & 2,308 & 0,647 & 8,231 \\
\hline Siyasi Görüş (6) & $-0,150$ & 0,361 & 0,174 & 1 & 0,677 & 0,860 & 0,424 & 1,745 \\
\hline Siyasi Görüş (7) & 0,343 & 0,411 & 0,695 & 1 & 0,405 & 1,409 & 0,629 & 3,156 \\
\hline Sabit & $-0,811$ & 1,700 & 0,228 & 1 & 0,633 & 0,44 & & \\
\hline
\end{tabular}

\section{Sonuç}

$\mathrm{Bu}$ araştırma,15-32 yaş aralığındaki gençlerin Suriyelilere yönelik zenofobik tutumları ile bu tutumlarını etkileyen sosyo-demografik özelliklerine odaklanmıştır.Araştırmada genel olarak gençlerin Suriyelilere yönelik zenofobik tutumlarının yüksek olduğu gözlenmiştir. Bulgu Budak ve arkadaşları (2018), Ergin (2006), Padır (2019) ile TÜRKSAM (2018) tarafindan çeşitli gruplarla yapılan araştırma bulgularıyla paralellik göstermektedir. Bu çalışmada ortaya çıkan bulguya bakarak gençlerin de halkın Suriyelilere yönelik eğilimlerinden etkilendiği söylenebilir. Suriyeli sığınmacıların sayılarının git gide artması, kültürel ve toplumsal uyumun sağlanamaması, boşanma oranlarının artması, çocuk işçilerin yaygınlaşması, çarpık yapılaşmanın artması, demografik yapının bozulması, kiralarda artış, işletmelerde kaçak işçi çalıştırmanın yaygınlaşması, Suriyeliler için harcandığı düşünülen bütçenin yüksekliği ile yine onlara verildiği söylenen sosyal haklar (burs, sınavsız eğitim, sosyal yardım, vb) gibi sebeplerle gençlerin zenofobik tutumları yükselmiş olabilir (Padır, 2019; TÜRKSAM, 2018). Bunun yanında medya da Suriyelilere yönelik çıkan olumsuz 
haberlerin de gençler üzerinde olumsuz etkisi olduğu söylenebilir. Sosyal medyayı etkin şekilde kullanan gençlerin ${ }^{1}$ özellikle Suriyelilere verildiği söylenen sınavsız eğitim hakk1 ve/veya işsizlikten Suriyelilerin sorumlu olduğu yönündeki haberler gençlerin algısını olumsuzlaştırmış olabilir. Nitekim katılımcıların "Göçmenler burada yaşayan insanların işlerini almaktadırlar" maddesinden yüksek puan almaları da iş anlamında onları bir tehdit olarak gördüklerini ortaya koymaktadır. Son olarak gençlerin aktif sosyal yaşamları gereği diğer gruplara kıyasla Suriyelilerle kamusal alanda karşılaşma ihtimallerinin yüksekliği de gençlerin zenofobik tutumlarını yükseltmiş olabilir. Gençler yaşları gereği zamanlarının büyük bölümünü ev dışında geçirmektedir. Bu da onların farklı insanlarla daha çok karşılaşma ve farklı deneyimler yaşama ihtimallerini yükseltmektedir. $\mathrm{Bu}$ deneyimler olumlu olabildiği gibi olumsuz da olabilmektedir. Suriyelilerle ilişkili sosyal yaşamda karşılaşılan olumsuz deneyimler gençlerin algısını negatif yönde değiştirebilmektedir (Kardeş vd. 2017).

Araştırmada gençlerin Türkiye sınırlarının göçmenlerin girişi için güvenli hâle getirilmesi gerekliliğine inandıkları da ortaya konmuştur. Bulgunun, sığınmacıların ülkede güvenlik sorunu oluşturduğu ve toplumun huzurunu bozduğu algısının kuvvetli olmasıyla ilişkili olabileceği düşünülmektedir. Nitekim yapılan çalışmalarda halkın bu yönde bir algıya sahip olduğu da ortaya çıkmıştır (Doğanay ve Çoban-Keneş, 2016; Kardeş vd., 2017). Ortadoğu Bölgesindeki siyasi ve ekonomik istikrasızlık, Irak ve Suriye de meydana gelen otorite boşluğu, bu ülkelerdeki terör örgütlerinin iç savaşın yol açtığı denetimsizlik ortamında çeşitli silahları ele geçirmeleri, terör örgütlerinin açık kapı politikasını firsat bilerek ülke içerisine silah ve mühimmat getirmeleri ve sınır kaçakçılarının faaliyetleri ülkenin güvenliğini tehlikeye sokmaktadır (Ağır ve Sezik, 2015). Bu durum ülkede bulunan göçmen ve sığınmacılara yönelik kuşkuyu artırmakta, göç politikasının gözden geçirilmesini gerekli kılmaktadır. Bu çalışmada gençlerin büyük kısmının Türkiye'de göç ve göçmenliğin kontrolden çıktığına inandıklarını söylemeleri de bu gerekliliği ortaya koymaktadır.

Araştırmada medeni durumun zenofobi düzeyini anlamlı şekilde yordadığı, evlilere kıyasla bekârların zenofobik tutumunun yaklaşık 5 kat daha yüksek olduğu saptanmıştır. Literatürde medeni durum ile zenofobi arasındaki ilişkiye odaklanan çalışmalar oldukça sınırlı olup (Butkus, Maciulyte-Sniukiene ve Matuzeviciute, 2016) elde edilen bulgular tutarsızdır. Örneğin Butkus ve arkadaşları (2016) çalışmalarında medeni durumun zenofobi üzerinde etkili olmadığını tespit ederken, Raijman (2003) bekarların daha zenofobik olduğunu saptamıştır. Bu durum söz konusu değişkenle ilişkili daha fazla çalışma yapılması gerekliliğini ortaya koymaktadır. Bu çalışmada bekârların daha zenofobik çıkmasının gelir düzeylerinin düşük olması (bekarların \%54'ü alt gelir düzeyine sahip olduğunu söylemiştir) ile ilişkili olabileceği düşünülmektedir. Nitekim bu çalışmada gelir düzeyi düştükçe zenofobik tutumun arttığı gözlenmiş̧ir. Bunun yanında bekarların güvensizlik algılarının yüksek olmasının da (bkz. Etaugh ve Malstrom, 1981) bu yönde bir bulgunun ortaya çıkmasında etkili olabileceği varsayılmaktadır. Bu çalışmaya katılanların \%72'si öğrencidir ve çoğunluğu (\%65) kente diğer şehirlerden gelmiştir. Kendilerini güvende hissetmelerini sağlayan yakın sosyal destek ağlarından (aile ve akraba gibi) uzak olmaları gençlerin yabancılara yönelik güvensizlik algılarını ve dolayısıyla onlara karşı olumsuz tutumlarını yükseltmiş olabilir.

Araştırmada beklenenden farklı şekilde eğitim düzeyinin zenofobik tutumu pozitif yönde etkilediği, lise mezunlarının ilköğretim mezunlarına kıyasla zenofobik tutumlarının oldukça yüksek olduğu saptanmıştır. Araştırma bulguları literatürle uyuşmamaktadır (bkz. Hjerm, 2001; HalperinPedahzur ve Canetti-Nisim, 2007). Bunun özellikle bir ve ikinci basamakta modern eğitim sisteminin ulus devletlerin milli değer ve simgelerini yeni nesillere aktaran ve böylece "biz" ve "öteki" arasındaki ayrımı netleştiren bir unsur olmasıyla ilişkili olabileceği düşünülmektedir.

\footnotetext{
${ }^{1}$ Sosyal medyada en kalabalık yaş grubu 25-34 yaş arasındadır. Bu yaş grubuna ait erkeklerin \%19'u, kadınların ise \%13'ü sosyal medya kullanıcısıdır. İkinci sırada 18-24 yaş grubu bulunmaktadır (https://wearesocial.com/globaldigital-report-2019).
}

Turkish Studies - Social, 15(1) 
Ancak eğitimin ayrımc1 düşünceler üzerindeki etkisinin daha doğru yorumlanabilmesi için diğer (gelir düzeyi ve yaş) değişkenlerle birlikte değerlendirilmesi gerekliliğinden (Hijerm, 2001) yola çıarak yapılan çapraz tabloda lise mezunu katılımcıların \%60'ının bekar olduğu, beşte birinin alt gelir düzeyine sahip olduğu saptanmıştır. Bulgular bir arada değerlendirildiğinde lise mezunlarının çoğunluğunun bekar olmasının ve alt gelir düzeyine sahip olmalarının zenofobik olmalarının altındaki gerçek nedenler olabileceği varsayılmaktadır.

Araştırmada son olarak alt gelir düzeyine sahip olanların daha zenofobik olduğu ortaya konmuştur. Araştırma bulguları literatürle uyuşmaktadır. Nitekim bulgumuzu destekleyecek şekilde Scheve ve Slaughter (2001) Amerika'da düşük beceriye sahip dolayısıyla daha az ücretle çalışan işçilerin göç ve göçmenlere yönelik bakışının olumsuz olduğunu saptamışlardır. Mayda (2006) ise yerli halkın daha yetenekli ve nitelikli, dolayısıyla yüksek gelir düzeyine sahip olduğu ülkelerde göçmenlere desteğin daha pozitif olduğunu ortaya koymuştur. Yine Neocosmos (2010)'un Afrika'da, Mocan ve Raschke (2014)'nin Almanya da yaptıkları çalışmada düşük gelir düzeyine sahip olanların daha zenofobik olduğu saptanmıştır. Bu çalışma kapsamında da ortaya çıkan bulgu yerli halk ile yabancılar arasında kıt ekonomik kaynaklara ulaşmak için yaşanan rekabetin (Blumer, 1958; Sherif, Harvey, White, Hood ve Sherif, 1961) bir sonucu olarak yorumlanabilir. Çünkü araştırmaya katılıp bir işte çalıştığını söyleyen düşük gelirlilerin \%38'i enformel sektörde çalıştıklarını söylemiştir. Yine öğrenci olup düşük gelire sahip olduklarını söyleyenlerin $\% 41$ 'i anne veya babalarının enformel sektörde çalıştıklarını beyan etmişlerdir. Düşük ücretle çalışanlar genellikle düşük statülü işlerde ve iş güvencesinden yoksun çalışmaktadır. Bu grup Türkiye'ye gelen ve çoğunluğu niteliksiz işgücünü oluşturan Suriyelilerle rekabet etmek durumundadır. Özellikle vasıfsız işgücü piyasasında yaşanan rekabet asgari ücretle çalışan yerli işçiler üzerinde işten çıkarma baskısı oluşturmakta (İşcan ve Çakır, 2019) ya da ücretlerinin düşmesine neden olmaktadır (Paas ve Halapuu, 2012). Bu da onların Suriyelilere yönelik olumsuz tutum geliştirmelerine neden olmuş olabilir.

\section{Öneriler ve Sinırlılıklar}

Özetle bu çalışmada gençlerin Suriyelilere yönelik algısının olumsuz olduğu, bekârların, lise mezunlarının ve düşük gelirli gençlerin daha zenofobik olduğu ortaya çıkmıştır. Elde edilen bulgular çerçevesinde yöneticilerin göç politikasını yeniden gözden geçirmesi, Suriyeli halk ile yerel halk arasındaki sosyal etkileşimi kuvvetlendirecek ve halkın kaygılarını giderecek politikalara yönelmesi gerekliliği ortaya çıkmıştır. Aksi takdirde gelecekte iki grup arasında hoşnutsuzluğun giderek artması kaçınılmazdır. Bu kapsamda kamu spotlarıyla, iletişim araçları ve gençlerin yoğun kullandığı sosyal medya yoluyla Suriyelilerle ilgili olumsuz haberlerin yanlışlığ Bunun yanında özellikle yerel belediyeler ve sivil toplum örgütleri her iki grubu bir araya getirecek etkinlikler hazırlayabilir. Üniversitelerde gençleri bilgilendirici konferanslar, seminerler, çalıştaylar düzenlenebilir. Son olarak tüm bölümlere göç, çok kültürlülük, insan hakları gibi dersler en azından seçmeli ders olarak açılabilir.

$\mathrm{Bu}$ çalışmanın ilk sınırlılığı nicel araştırma yöntemiyle yapılmasıdır. Dolayısıyla gençlerin neden zenofobik olduğuna yönelik kapsamlı ve ayrıntılı bir değerlendirme yapmak zordur. Gençlerin zenofobik tutumlarının gerçekten neden kaynaklandığını net olarak ortaya koyabilmek için hem nicel hem de nitel araştırma yöntemlerinin birlikte kullanıldığı karma araştırmaların yapılması gerekliliği ortaya çıkmıştır.

Araştırma kolayda örnekleme tekniğiyle yapıldığından katılımcıların çoğunluğu üniversite öğrencilerinden oluşmuştur. İşsiz gençler araştırmada az sayıda temsil edilme imkanı bulmuştur. Dolayısıyla gelecekteki çalışmalarda olasılıklı örnekleme tekniklerini kullanmanın önemli olduğu düşünülmektedir. 
Çalışmanın bir diğer sınırlılığı kesitsel bir araştırma olmasıdır. Gençlerin zaman içerisinde Suriyelilere yönelik tutumlarının değişip değişmediğini veya değişiyorsa ne yönde değiştiğini ortaya koymak için uzunlamasına araştırmaların yapılmasına ihtiyaç vardır.

\section{Kaynakça}

Aden, A. A. (2017). An Instance of Xenophobia: An Investigation into the Violence Against Somali Traders in Khayelitsha (Yayımlanmamış yüksek lisans tezi). University of the Western Cape Faculty of Economicand Management Sciences, Cape Town.

Ağır, O. ve Sezik, M. (2015). Suriye'den Türkiye'ye Yaşanan Göç Dalgasından Kaynaklanan Güvenlik Sorunları. Birey ve Toplum, 5(9), 95-124.

Akcan, A. T. (2018). Türkiye İşü̈cü Piyasasında Suriyeli Sığınmacıların Yeri ve Etkileri. Sosyal Güvenlik Dergisi, 8 (2), 59-73.

Al-Kubaisi, F. ve Soliman, A. (2017). Socio-DemographicandCognitiveDeterminants of Xenophobiaamongthe GCC Citizens. EuropeanPsychiatry, 41, 518.

Baş, T. (2010). Anket Nasıl Hazırlanır? Anket Nasıl Uygulanır? Anket Nasıl Değerlendirilir? (6. bask1). Ankara: Seçkin Yayıncılık

Best, H. ve Wolf, C. (2015). Logistic Regression. H. Best, ve C. Wolf, (Ed.), The SAGE Handbook of Regression Analysis and Causal Inference içinde (pp. 153-172). London: Sage.

Blumer, H. (1958). Race Prejudice as a Sense of Group Position. Pacific Sociological Review, 1(1), 3-7.

Budak, P., Demir, M.S., Tan, M. ve Sarı, M. (2017). Yerel Halkın Algısında Suriyeli Sığınmacılar ve Toplumsal Etkileri: Elazığ İli Örneği. Akademik Sosyal Araştırmalar Dergisi, 5(62), 543-56. https://doi.org/10.16992/asos.13262

Butkus, M., Maciulyte-Sniukiene, A., Matuzeviciute, K. (2016), Socio-Demographic Factors Influencing Attitude Towards Refugees: An Analysis of Data From European Social Survey. 16th International Scientific Conference Globalization and its Socio-Economic Consequences, 5th - 6th October 2016, s. 286-294.

Campbell, D. T. ve McCantless, B. R. (1951). Ethnocentrism, Xenophobia and Personality. Human Relations, 4(2), 185-192.

Cashdan, E. (2001). Ethnocentrism and Xenophobia: A Cross-cultural Study. Current Anthropology, 42(5), 760-764.

Chandler, C. R. ve Tsai, Y-M. (2001). Social Factors Influencing ImmigrationAttitudes: An Analysis of Data From the General SocialSurvey. The Social Science Journal, 38(2), 177188.

Çiftçi, H. (2018). Türkiye Cumhuriyeti Vatandaşlarının Suriyeli Sığınmacılara Yönelik Tutum, Algı ve Empatik Eğilimlerinin Analizi. Insan ve Toplum Bilimleri Araştırmaları Dergisi, 7 (3), 2232-2256. https://doi.org/10.15869/itobiad.450230

De Master, S. ve Le Roy, M. (2000). Xenophobia and the European Union. Comparative Politics, 32(4), 419-436. doi:10.2307/422387

Doğanay, Ü. ve Çoban Keneş, H. (2016). Yazılı Basında Suriyeli 'Mülteciler': Ayrımc1 Söylemlerin Rasyonel ve Duygusal Gerekçelerinin İnşası. Mülkiye Dergisi, 40 (1), 143184.

Turkish Studies - Social, 15(1) 
Ekehammer, B., Akrami, N., Gylje, M., ve Zakrisson, I. (2004). What Matters Most to Prejudice: Big Five Personality, Social Dominance Orientation, or Right-Wing Authoritarianism? EuropeanJournal of Personality, 18(6),463-482.

Ergin, H. (2006). Türkiyeli Üniversite Öğrencilerinin Suriyeli Sınıf Arkadaşlarına Yönelik Algıları. Ĕ̈itim ve Bilim, 41(184), 399-415.

Etaugh, C. ve Malstrom, J. (1981). Th eEffect of MaritalStatus on Person Perception. Journal of Marriage and the Family, 43(4), 801. doi:10.2307/351337

Fırat, S. Ü. (1997). Kümeleme Analizi: İstihdamın Sektörel Yapısı Açısından Avrupa Ülkelerinin

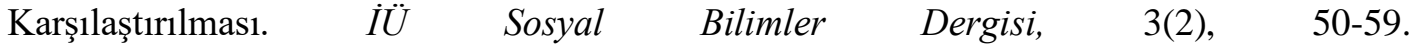
https://doi.org/10.17218/hititsosbil.288133

Gallego, A. ve Pardos-Prado, S. (2014) The Big Five Personality Traits and Attitudes towards Immigrants, Journal of Ethnic and Migration Studies, 40(1), 79-99, DOI:10.1080/1369183X.2013.826131

Getmansky, A., Sinmazdemir, T. ve Zeitzoff, T. (2018). Refugees, Xenophobia, and Domestic Conflict: Evidence From a Survey Experiment in Turkey. Journal of Peace Research, 55(4), 491-507. https://doi.org/10.1177/0022343317748719

Güngör, F. Ş. (2017). Zenofobi ve Ötekinin Dikeni. G. B. Dursun ve T. Korkmaz, (Ed.), Uluslararası İnsan ve Toplum Bilimleri Kongresi Bildiri Kitabı içinde (ss. 209-214). Ankara: Gazi Üniversitesi Yayınları. https://doi.org/10.16947/fsmia.372656

Hainmueller, J. ve Hopkins, D. J. (2014). Public Attitudes Toward Immigration. Annual Review of PoliticalScience, 17, 225-249.

Hair, J.F., Black, W.C., Babin, B.J.ve Anderson, R. E. (2014). Multivariate Data Analysis (7th Edition). Pearson.

Halperin, E., Pedahzur, A. ve Canetti-Nisim, D. (2007). Psychoeconomic Approaches to the Study of HostileAttitudes Toward Minority Groups: A Study among Israeli Jews. Social Science Quarterly, 88(1), 177-198.

Harris, B. (2002). Xenophobia: A New Pathology for a New South Africa? Hook, D. Ve Eagle, G. (Ed.). Psychopathology and Social Prejudice içinde (pp.169-184). Cape Town:University of Cape TownPress.

Hjerm, M. (2001). Education, Xenophobia and Nationalism: A Comparative Analysis. Journal of Ethnicand Migration Studies, 27(1), 37-60.

Hovey, J. D. (2000). Acculturative Stress, Depression, and Suicidal ideation in Mexican Immigrants. Cultural Diversity and Ethnic Minority Psychology, 6, 134-151.

Lakimova, O. (2018). Exploring the Dynamics of Xenophobia in the Nordic Countries. Changing Societies \& Personalities, 2(1), 17-31.

İşcan, İ. H. ve Çakır, M. Türkiye'deki Sığınmacı ve Mültecilerin Türk İşü̈cü Piyasasına Etkisi: Bir Saha Araştırması. Sosyal Politika Çalışmaları Dergisi, 19(43), 177-236. https://doi.org/10.21560/spcd.v19i46288.479503

Jasinskaja-Lahti, I., Liebkind, K. Ve Perhoniemi, R. (2006). Perceived Discrimination and Wellbeing: A Victim Study of Different Immigrant Groups. Journal of Community Applied Social Psychology, 16(4), 267-284.

Kaplan, İ. (2019). Türkiye'de Milli Eğitim İdeolojisi. İletişim Yayınları. 
Kardeş, S., Banko, Ç. ve Akman, B. (2017). Sosyal Medyada Suriye'li Sığınmacılara Yönelik Algı: Bir Sözlük Değerlendirmesi. Göç Dergisi, 4(2), 185-200. https://doi.org/10.33182/gd.v4i2.596

Kılıç, S. (2015). İki Durumlu Lojistik Regresyon Analizi. Journal of MoodDisorders, 5 (4), 191194.

King, R. D. (2007). Group Threat and Social Control: Race, Perceptions of Minorities and the Desire to Punish. Social Forces, 85(3), 1255-1280.

Lesetedi, G. N. ve Modie-Moroka, T. (2007). Reverse Xenophobia: Immigrants Attitudes Towards Citizens in Botswana. In African Migrations Workshop: Understanding Migration Dynamics in the Continent, Centre for Migration Studies, University of Ghana, LegonAccra, Ghana.

Litvinova, A. V. ve Tarasov, K. (2012). The Psychological Determinants Causing Tendency to Xenophobia at Students of Humanitarian Colleges. Problems of Psychology in the 21st Century, 3, 60-66.

Loescher, G. Ve Milner, J. (2004). Protracted Refugee Situations and State and Regional in Security: Analysis. Conflict, Security ve Development, 4(1), 3-20.

Makgopa, M. (2013) A Critical Evaluation of the Key Theoretical Concepts and models on Xenophobia as Depicted in the Drama of MS Serudu's Nagagadietelane: A QualitativeApproach. South AfricanJournal of AfricanLanguages, 33(2), 115-123.

Mayda, A. M. (2006). Who is Against Immigration? A Cross-Country Investigation of Individual Attitudes toward Immigrants. The Review of Economics and Statistics, 88(3), 510-530.

Miller, S.D. (2018). Xenophobia Toward Refugees and Other Forced Migrants (Research paper No. 5). Waterloo, Canada: Centrefor International Governance Innovation.

Mocan, H. N. ve Raschke, C. (2014) :Economic Well-beingand Anti-Semitic, Xenophobic, and Racist Attitudes in Germany. IZA DiscussionPapers, No. 8126, Institute for the Study of Labor (IZA), Bonn

Neocosmos, M. (2010). From 'Foreign Natives' to 'Native Foreigners' Explaining Xenophobia in Post-apartheid South Africa: Citizenship and Nationalism, Identity and Politics. Dakar: African Books Collective.

Nurdoğan, A.K. ve Doğan, Z, (2019), Türkiye'ye Yönelen Uluslararası Göç Hareketliliği Bağlamında Çorum Il Görünümü, $B E \ddot{U} \quad A \dot{I} D, \quad 4(1), \quad 125-143$. https://doi.org/10.26466/opus.569989

Odiaka N. (2017). The Face of Violence: Rethinking the Concept of Xenophobia, Immigration Laws and the Rights of Non-Citizens in South Africa. Brics Law Journal, 4(2), 4070. https://doi.org/10.21684/2412-2343-2017-4-2-40-70

Orhan, O. ve Gündoğar, S. Ş. (2015). Suriyeli Siğınmacıların Türkiye’ye Etkileri. Ankara: ORSAM Yayını.

Osmanoğlu, A. E. (2013). Türkiye ve Mısır Sosyal Bilgiler Ders Kitaplarında Milliyetçi Değerler: Karşılaştırmalı Bir Analiz. $\quad$ TurkishStudies, 8(8), 989-1012. https://doi.org/10.7827/turkishstudies.5483

Özdemir, E. (2017). Suriyeli Mülteciler Krizinin Türkiye'ye Etkileri. Uluslararası Kriz ve Siyaset Araştırmaları Dergisi, 1(3), 114-140. 
Özmete, E., Yıldırım, H. Ve Duru, S. (2018). Yabancı Düşmanlığı (Zenofobi) Ölçeğinin Türk Kültürüne Uyarlanması: Geçerlik ve Güvenirlik Çalışması. Sosyal Politika Çalışmaları Dergisi, 18(40/2), 191-209. https://doi.org/10.21560/spcd.v18i39974.451063

Paas, T. ve Halapuu, V. (2012). Attitudes Towards Immigrants and the Integration of Ethnically Diverse Societies. Eastern Journal of European Studies, 3(2).

Padır, M. A. (2019). Examining Xenophobia in Syrian Refugees' Context: The Roles of Perceived Threats and Social Context (Yayımlanmamış Doktora tezi). Orta Doğu Teknik Üniversitesi Sosyal Bilimler Enstitüsü, Ankara.

Ponce, A. (2017). Genderand Anti-Immigrant Attitudes in Europe. Socius: SociologicalResearchfor a Dynamic World, 3, 1-17.

Quillian, L. (1995). Prejudice as a Response to Perceived Group Threat: Population Composition and Anti-immigrant and Racial Prejudice in Europe. American Sociological Review, 586611.

Radkiewicz, P. (2003). The National Values as a Concept Helpful in Explaining the Development of NationalisticAttitudes and Xenophobia. Polish Psychological Bulletin, 34, 5-13.

Raijman, R., Semyonov, M. ve Schmidt, P. (2003). Do Foreigners Deserve Rights? Determinants of Public Views towards Foreigners in Germany and Israel. European Sociological Review, 19(4), 379-392.

Reynolds, V., Falger, V., ve Vine, I. (1987). The Sociobiology of Ethnocentrism: Evolutionary Dimensions of Xenophobia, Discrimination, Racism and Nationalism. Athens: University of Georgia Press.

Rydgren, J. (2004). TheLogic of Xenophobia. Rationality and Society, 16, 123-148.

Sanchez-Mazas, M., ve Licata, L. (2015). Xenophobia: Social Psychological Aspects. James D. Wright (editor-in-chief), International Encyclopedia of the Social \& Behavioral Sciences (2nd edition, Vol 25) içinde (pp. 802-807). Oxford: Elsevier.

Scheve, K. F. ve Slaughter, M. J. (2001). Labor Market Competition and Individual Preferences over Immigration Policy. Review of Economics and Statistics, 83(1), 133-145.

Schlueter, E. ve Wagner, U. (2008). Regional Differences Matter: Examining the Dual Influence of the Regional Size of theImmigrant Population on Derogation of Immigrants in Europe. International Journal of Comparative Sociology, 49(2-3), 153-173.

Schweitzer, R., Perkoulidis, S. A., Krome, S. L. ve Ludlow, C. N. (2005). Attitudes Towards Refugees: The Dark Side of Prejudice in Australia. AustralianJournal of Psychology, 57(3): 170-179. https://doi.org/10.1080/00049530500125199

Sherif, M., Harvey, O. J., White, B. J., Hood, W. R. ve Sherif, C. W. (1961). Intergroup Cooperation and Competition: The Robbers Cave Experiment. Norman, OK: University Book Exchange.

Sherrod, L. R. (Ed.). (2006). Youth Activism: An International Encyclopedia (2. Cilt). Greenwood Publishing Group.

Strabac, Z. ve Listhaug, O. (2008). Anti-MuslimPrejudice in Europe: A Multilevel Analysis of Survey Data from 30 Countries. Social Science Research,37(1), 268-286. https://doi.org/10.1016/j.ssresearch.2007.02.004

Sundstrom, R. R. (2013). Sheltering Xenophobia. Critical Philosophy of Race, 1(1), 68-85. 
Şener, G., Yücel, H. ve Yedikardeş, U. (2018). Siyasi Parti Üyesi Gençlerin Sosyal Medya Kullanımı Araştırması, TÜSES.

Tajfel, H. Ve Turner, J. (1979). An Integrative Theory of Intergroup Conflict. Austin, W. G. Ve Worchel, S. (Eds.) The Social Psychology of Inter Group Relations içinde (ss.3347). California: Brooks-Cole.

TÜRKSAM (2018). Türk Halkının Suriyeli Sığınmacı/Mülteci Algısı. Erişim tarihi: 2 Ekim 2019. Erişim adresi: http://turksam.org/dosyalar/2018/07/TU\%CC\%88RKSAM-RaporI\%CC\%87c\%CC\%A7.pdf

UNHCR (2015). Protection from Xenophobıa. Erişim tarihi: 2 Ekim 2019. Erişim adresi: https://www.unhcr.org/research/evalreports/55cb153f9/protection-xenophobia-evaluationunhcrs-regional-office-southern-africas.html

UNHCR (2018). World Migration Report (2018). Erişim tarihi 2 Ekim 2019. Erişim adresi: https://www.iom.int/sites/default/files/country/docs/china/r5_world_migration_report_201 8_en.pdf

Van der Veer, K., Yakushko, O., Ommundsen, R. ve Higler, L. (2011). Cross-National Measure of Fear-Based Xenophobia: Development of a Cumulative Scale. Psychological Reports, 109(1), 27-42. https://doi.org/10.2466/07.17.PR0.109.4.27-42

Wimmer, A. (1997). Explaining Xenophobia and Racism: A Critical Review of Current Research Approaches. Ethnic and Racial Studies, 20(1), 17-41.

Yakushko, O. (2009).Xenophobia: Understanding the Roots and Consequences of Negative Attitudes toward Immigrants. The Counseling Psychologist, 37(1), 36-66.

Koç, S. (2001). İllerin Sosyo-ekonomik Özelliklere Göre Sinıflandırılması. Çukurova Üniversitesi 5. Ulusal Ekonometri ve İstatistik Sempozyumu (Bildiri), Çukurova Üniversitesi, Adana.

https://www.un.org/esa/socdev/documents/youth/fact-sheets/youth-definition.pdf

https://www.unhcr.org/tr/unhcr-turkiye-istatis).

https://multeciler.org.tr/turkiyedeki-suriyeli-sayisi-ekim-2019/

https://www.trthaber.com/haber/dunya/suriyeliler-6-kitada-127-ulkeye-dagildi-420182.html 